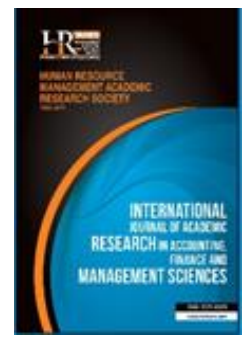

International Journal of Academic Research in Accounting, Finance and Management Sciences

Vol. 9, No.1, January 2019, pp. 80-93 E-ISSN: 2225-8329, P-ISSN: 2308-0337

(C) 2018 HRMARS

www.hrmars.com

To cite this article: Djuri, P. A., Darwis Said, D., Amiruddin (2019). The Effect of Lifestyle, Work Environment and Career Path of Accounting Bachelor on the Selection of Accounting Profession with Money Oriented as Moderating Variables, International Journal of Academic Research in Accounting, Finance and Management Sciences 9 (1): 8093.

http://dx.doi.org/10.6007/IJARAFMS/v9-i1/5770 (DOI: 10.6007/IJARAFMS/v9-i1/5770)

\title{
The Effect of Lifestyle, Work Environment and Career Path of Accounting Bachelor on the Selection of Accounting Profession with Money Oriented as Moderating Variables
}

\author{
Phatra A. Djuri ${ }^{1}$, Darwis Said ${ }^{2}$, Amiruddin ${ }^{3}$ \\ 1,2,3 Department of Accounting, Hasanuddin University, Makassar 90241, South Sulawesi, Indonesia, \\ ${ }^{1}$ E-mail: phatra.anggana@gmail.com
}

\begin{abstract}
The aim for this study is twofold. First, to identify the impact of lifestyle, work environment and career path accounting bachelor on the selection of accounting profession. Second, to examine the moderating role played by money oriented in the impact of lifestyle, work environment and career path accounting bachelor on the selection of accounting profession. Data were gathered by a questionnaire developed base on the literature, validated using exploratory and confirmatory factor analyses, and distributed to representative sample consisted by 105 accounting bachelor of Hasanuddin University in South Sulawesi. IBM SPSS was used to analyze 97 questionnaires that returned. The result revealed that lifestyle; work environment and career path has a significant impact on selection of accounting profession. Furthermore, the result indicated that money oriented significantly moderated the impact of lifestyle, work environment and career path accounting bachelor on the selection of accounting profession. A crucial contribution of this study is that it provides evidence in relation of lifestyle, work environment and career path on selection of accounting profession. Hence, academic and accounting organizations should pay a great attention to lifestyle, work environment and career path of accounting bachelor on study period to enhance intention of selection on accounting profession.
\end{abstract}

Key words Lifestyle, Work Environment, Career Path, Money Oriented, Accounting Profession

Received: 15 Apr $2019 \quad$ C The Authors 2019

Revised: 30 Apr 2019 Published by Human Resource Management Academic Research Society (www.hrmars.com)

Accepted: 15 May 2019 This article is published under the Creative Commons Attribution (CC BY 4.0) license. Anyone may reproduce, distribute, translate and create derivative works of this article (for both commercial and non-commercial purposes), subject to full attribution to the original publication and authors. The full terms of this license may be seen at: http://creativecommons.org/licences/by/4.0/legalcode

\section{Introduction}

In this millennial era the selection of current jobs for students after completing studies is a beginning in forming a career path. Students when the study process has a post-graduation plan for a career, both in accordance with the field of study during study or work in general. The number of jobs created both in the formal and creative industries, so that the career choice for scholars in this era is not limited to the scope of the focus of his studies. Bachelor from the accounting field in particular, is one of the fields of science that can reach many fields of work within an organization or company.

Generally, there are several alternative jobs to be undertaken by students after becoming scholars. First, after their scholars continue their careers to work, secondly, they continue their studies to a post graduated which later become accounting lecturers, and thirdly continue their accounting profession education. Accounting profession is an appropriate profession for accounting scholars, but does not require 
an accounting scholar to choose the profession. Reporting from the media kompas.com (2018) states that the number of professional accountants is still smaller than the total graduates of accounting majors in Indonesia. The average graduate is estimated to reach 35,000 per year while around 22,000 accountants are listed in the IAI. This explains that there is a lack of interest in accounting graduates in choosing a profession as an accountant.

In Abidin's research (2017) several factors were found which influenced a person's desire to choose accountants as a profession. The faculty includes financial awards, professional recognition, professional training, social values, pride, labour market considerations, work intrinsic value and personality towards the selection of professions as public accountants. In general, there are several theories in the world of education that discuss the factors that influence a person in career selection. Super (1957) revealed that through the theory of vocational self-concept it shows that physical and mental growth, the general environment, and experience in general are a self-concept which is a driving force that forms a career pattern that will be followed by individuals throughout their lives.

Stole stated in Aryani and Erawati (2016) that a career in the public accounting office is a career that provides financial rewards and varied work experience. A career at a Public Accountant Office can generate higher or greater income than the income earned from other careers. Money becomes a supporting factor for one's lifestyle. Some people if they perceive money as everything in life in other words dependence on the existence of money, so they will not seek satisfaction or achievement in work but companies that can provide a larger number chosen for a career and the possibility of loyalty to professional ethics will diminish, perception people about money can also change someone's working conditions. Centrally, the aim of the present study is to question the role of money oriented in the impact of lifestyle, work environment and career path of accounting bachelor on choosing accounting profession.

\section{Theoretical review and Hypotheses}

\subsection{The Vocational Personalities and Work Environment Theory}

According to Holland (1973), Individuals are attracted to a particular career because of their personality and various variables behind it. Basically, career choice is the expression or expansion of personality into the world of work followed by identification of certain occupational stereotypes. Comparison between self and perceptions of occupation and acceptance or rejection are the main determinants of career choices. Harmony between one's view of him and his preferred occupation forms a "personal orientation model".

Personal pleasure orientation (personal orientation model) is a developmental process that is formed through the heredity and life experience of individuals in reacting to the demands of their environment. Central to Holland's theory is the concept that individuals choose a career to satisfy their personal pleasure orientation. Concealing Career theory John Holland (1973) tried to explain how individuals choose careers that are in accordance with the type, nature and characteristics of the psychologist (personality) with the environmental model.

Individuals and environments interact with each other through six different types, namely realistic, intellectual, social, conventional, business and artistic. In this grouping, the conventional type is perceived as the type that approaches the accounting field. This type of model enjoys well-structured language and activities that are numerical, conformist, avoid blurred situations, and problems involving interpersonal relationships and physical skills, work effectively on well-organized work assignments, identify themselves with power, and give high value to material status and wealth. Vocational preferences include: bank supervisors, book holders, statisticians, financial analysis and accounting.

\subsection{Self-Concept Theory}

Self-concept Theory according to Super (1957) is a multidisciplinary approach to career development that is reflected in his interest in differential psychology or trait-and-factor theory as a medium for developing instrument testing and accompanying assessment norms. He argues that differential psychology is very important in an effort to enrich data about occupational differences related to personality, aptitude, and interest. 
Self-concept theory Is a self-image or self-concept in connection with the work to be carried out based on observations of adults, appreciation of life and the influence received from the environment. The self-image fosters an internal drive that leads to a field to achieve satisfaction. There are two components that are formed from this theory, namely personal components and social components. personal or psychological, which focuses on the way individuals choose and adapt to their choices; and social, which focuses on the personal assessment carried out by the individual on his socioeconomic situation and the social structure in which he currently works and lives.

\subsection{Occupational Choice Theory}

Ginzberg et al. (1951) are generally seen as the first experts to approach occupational choice theory from a developmental perspective. Ginzberg et al. (1951) concluded that occupational choice is a developmental process, which generally covers a period of six to ten years, which starts from around the age of 11 years and ends after age 17 or early adulthood. There are three periods or stages in the process of occupational selection, namely fantasy, tentative, and realistic periods.

Ginzberg et al. (1951) acknowledged the existence of individual variations in the process of making career decisions. Individual patterns of career development that are not in accordance with their peers are called deviant. There are two main causes of this deviation, namely that occupational skills that have developed well early often produce an early career pattern, which deviates from normal development and timings for the stage of realistic development that may be significantly slower in coming as a result of certain variables such as emotional instability, various personal problems, and financial wealth.

\subsection{Expectancy Theory}

Expectation theory is one of the motivational theories that use engagement based on expectations for a matter that will influence the actions that will be done in the future, so that he can achieve maximum results according to one's expectations. More fully, Vroom (1964) explains that the motivation of an individual leads to an action that depends on the power of hope. The action will be followed by certain results and depends on the results for that person. This theory argues that someone will be motivated to do something to achieve the goal if they believe that their behavior leads to achieving that goal.

According to Vroom (1964), there are three aspects that influence motivation, namely expectations, instruments and valence. Expectation (E) that is how likely it is if they perform certain behaviors they will get the expected work results (i.e. high work performance). Instrument (I) is how much the relationship between work performance and higher work results (i.e. income, either in the form of salary or other things given by the company). Valence $(\mathrm{V})$ is how important a person assesses the income given by the company to him, for example if the thing that is most coveted by one at a time, promotion, then that means for him the promotion occupies the highest valence.

\subsection{Hypothesis}

Holland (1973) through the theory of vocational personalities and work environment career guidance states that individuals are attracted to a particular career because of their personality and various variables behind it. Basically, career choice is the expression or expansion of personality into the world of work followed by identification of certain occupational stereotypes.

Djatej et al. (2015) explained the factors of students majoring in accounting. The author provides one factor that concerns a person's interest in choosing an accounting department, namely personal interest. In this case personal interest factors can be said to be an interest in a person towards something. In this study states that personal interest gives a positive influence on someone in choosing an accounting department. Based on the description previously stated, the first hypothesis in this study is as follows.

\section{$H_{1}$ : Lifestyle has a significant effect on the selection of accounting profession}

Super (1957) reveals that through the theory of vocational self-concept it shows that physical and mental growth, the general environment, and experience in general is a self-concept which is a driver that forms a career pattern that will be followed by individuals throughout their lives. There are two components that are formed from this theory, namely the personal component that focuses on the way 
individuals choose and adapt to their choices and social focus on personal assessment of the socioeconomic situation and social structure in which they work and live today.

Stolle in Kania (2013) revealed that the company's accounting profession according to the perceptions of accounting students is more routine and many jobs can be completed behind the desk, while jobs as public accountants are more attractive, more time-consuming, more competitive and more pressure to produce jobs better. The nature of the work, the level of competition and the amount of pressure are work environment factors. Based on the description previously stated, the second hypothesis in this study is as follows.

\section{$\mathrm{H}_{2}$ : Work environment has a significant effect on the selection of accounting profession}

Vroom (1964) in expectations theory or expectation theory states that the motivation of an individual leads to an action that depends on the power of hope. The action will be followed by certain results and depends on the results for that person. This theory argues that someone will be motivated to do something to achieve the goal if they believe that their behavior leads to achieving that goal. According to Vroom (1964), there are three aspects that influence motivation, namely expectations, instruments and valence. Expectation $(E)$ that is how likely it is if they perform certain behaviors they will get the expected work results. Instrument $(\mathrm{I})$ is how much the relationship between work performance and higher work results. Valence $(\mathrm{V})$, which is how important someone assesses the income given by the company.

Jean and Mathieu (2015) in his research on how a person can survive as an entrepreneur with one of the factors based on the satisfaction of his career. This study states that career development satisfaction has a relationship with how one can survive to become an entrepreneur. Based on the description previously stated, the third hypothesis in this study is as follows.

\section{$\mathrm{H}_{3}$ : Career path has a significant effect on the selection of accounting profession}

In occupational choice theory by Ginzberg et al. (1951) states that in a tentative period there is an initial stage involving interest, where individuals make more definitive decisions about likes or dislikes. In theory, Ginzberg et al. (1951) realized that there were individual variations in the process of making career decisions called deviations in the career selection process. There are two main causes of this deviation, namely Occupational Skills that have developed well early often produce early career patterns as well, which deviate from normal development and the timing for realistic developmental stages may be significantly slower in coming as a result of certain variables such as emotional instability, various personal problems, and financial wealth.

According to Kraus research Reported by Vice Media Online (2017) conducted in the United States, said money can affect the character or lifestyle and environment. Rich people tend to be more narcissistic and think they are more capable and capable than ordinary people, whereas those who are not rich, on the contrary have lower levels of control of the surrounding environment and tend to be more usual empathetic, loving and kind. Based on the description previously stated, the fourth hypothesis in this study is as follows.

\section{$H_{4}$ : Money oriented has a moderating role play in the impact of lifestyle on the selection of accounting profession}

In occupational choice theory by Ginzberg et al. (1951) states that in a tentative period there is an initial stage involving interest, where individuals make more definitive decisions about likes or dislikes. In theory, Ginzberg et al. (1951) realized that there were individual variations in the process of making career decisions called deviations in the career selection process. There are two main causes of this deviation, namely Occupational Skills that have developed well early often produce early career patterns as well, which deviate from normal development and the timing for realistic developmental stages may be significantly slower in coming as a result of certain variables such as emotional instability, various personal problems, and financial wealth.

Money can affect the character or lifestyle and environment. Rich people tend to be more narcissistic and think they are more capable and capable than ordinary people, whereas those who are not rich, on the contrary have lower levels of control of the surrounding environment and tend to be more 
usual empathetic, loving and kind. This report has been researched by Yelsinta and Fuad (2013) and Kraus (2017). Based on the description previously stated, the fifth hypothesis in this study is as follows.

$H_{5}:$ Money oriented has a moderating role play in the impact of work environment on the selection of accounting profession

Vroom (1964) in expectations theory or expectation theory states that the motivation of an individual leads to an action that depends on the power of hope. The action will be followed by certain results and depends on the results for that person. This theory argues that someone will be motivated to do something to achieve the goal if they believe that their behavior leads to achieving that goal. According to Vroom (1964), there are three aspects that influence motivation, namely expectations, instruments and valence. Expectation $(\mathrm{E})$ that is how likely it is if they perform certain behaviors they will get the expected work results. Instrument $(\mathrm{I})$ is how much the relationship between work performance and higher work results. Valence $(\mathrm{V})$, which is how important someone assesses the income given by the company.

In Sartono's research (2018) regarding Turn-Over Intention or a comparison between the entry and cessation of employees in a company. In the study it was found that one of the variables that significantly or negatively affected was the variable regarding compensation while compensation itself is something in the form of money or goods received by employees of the company. Based on the description previously stated, the sixth hypothesis in this study is as follows.

$H_{6}$ : Money oriented has a moderating role play in the impact of career path on the selection of accounting profession

\section{Research Model}

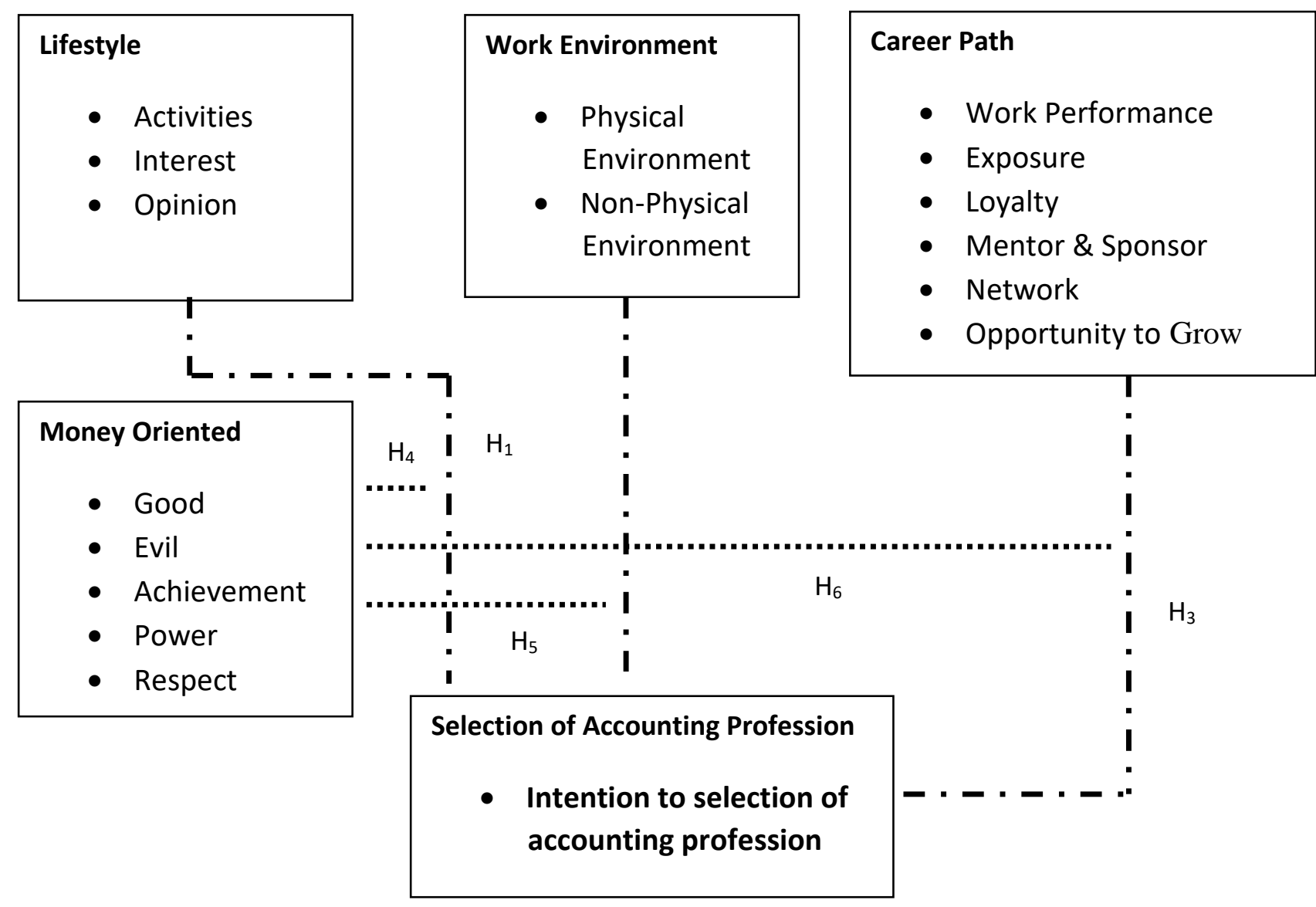

Figure 1. Research model

Figure 1 show the research conceptual model. It contains three construct: lifestyle, work environment and career path as independent variables, money oriented as moderate variables and selection of accounting profession as dependent variables. Lifestyle is a consumption pattern that reflects 
individual choices in terms of how they spend money and time (Suryani, 2013). Lifestyle use psikografis method for measuring, that namely AIO dimension. AlO is activities, interests and opinions.

Work environment is everything that exists around the work and that can influence him/her in carrying out the assigned tasks (Nitisemito, 2013) states that broadly speaking, the type of work environment is divided into two namely non-physical work environment and physical work environment (Sedarmayanti, 2013). Measurement factors in work environment are physical environment and nonphysical environment. Career Path is a process that is passed by individual employees to identify and take steps to achieve their career goals (Sunyoto, 2013). Measurement factors in career path are work performance, exposure, loyality, mentor and sponsor, networking and opportunity to grow (Rivai et al., 2018).

Money Oriented is individual behavior and opinion of money. How an individual perceives money in his life and how he treats money for his daily life. In this case, love of money theory from tang (2008) can explain the money oriented phenomenon. Tang (2008) defines love of money as a person's behavior towards money, one's understanding of money, and one's wishes and aspirations for money. Love of money can also be interpreted as the level of one's love for money, how they consider the importance of money for their lives. Money ethic scale (MES) produces six identified factors, including good, evil, achievement, respect, budget, and freedom. The measurement of the accounting profession is based on the desire of someone to choose the accounting profession as a goal for a career. Ajzen (1967) in Mahyarni (2013) states that is the desire to behave that reflects the hardness of someone's willingness to try and how to motivate the person to do a behavior.

\section{Methodology of research}

This research is causal and explanatory research, which causes independent variables to influence the dependent variable. The location of the study was conducted at Hasanuddin University, Makassar City, South Sulawesi Province and will take place for a period of one semester or six months. The population in this study was graduates of accounting at Hasanuddin University, Makassar City; the graduation period takes five years period from 2013 till 2017. The population in this study was 856 people. This study uses the Slovin formula because in sampling, the number must be representative so that the results of the study can be generalized and the calculations also do not require a table of samples so that the sample obtained is 90 samples for this research. This research use IBM SPSS for analysis data for validity, reliability and classic assumption test. Use multiple regression analysis to test the impact of independent variables on dependent variables. Whereas, this research use moderating regression analysis to test the role play of moderate variables.

\section{Results and Discussions}

The results of this study were obtained through data collection in the form of questionnaires totaling 97 questionnaires that were distributed face-to-face with scholars of accounting at Hasanuddin University and supported by dissemination through social media in the group during the study at Hasanuddin University using a smartphone. The distribution of questionnaires was done face-to-face directly or through private media as many as 105 copies. Questionnaires that were responded to as many as 97 copies with a percentage return rate of $92.4 \%$ is a very high category in the rate of return.

Table 1. Demographic Table

\begin{tabular}{|c|c|c|}
\hline Demographic Characteristic & Category & Rate \\
\hline \multirow{2}{*}{ Gender } & Laki-laki & $43,30 \%$ \\
\hline & Perempuan & $56,70 \%$ \\
\hline \multirow{3}{*}{ Age } & 21-25 Years & $60,82 \%$ \\
\hline & 26-29 Years & $31,98 \%$ \\
\hline & $>30$ Years & $7,20 \%$ \\
\hline \multirow{5}{*}{ Graduation Years } & 2013 & $28,86 \%$ \\
\hline & 2014 & $13,40 \%$ \\
\hline & 2015 & $25,77 \%$ \\
\hline & 2016 & $11,34 \%$ \\
\hline & 2017 & $20,61 \%$ \\
\hline
\end{tabular}


Questionnaires that were processed as many as 97 copies consisting of accounting bachelor from Hasanuddin University in 2013 were 28,86\%, in 2014 there were 13,40\% , in 2015 there were 25,77\% , in 2016 there were $11,34 \%$ and in 2017 there were $20,61 \%$. Female respondents were indicated $56.70 \%$, while male respondents who participated were smaller compared to female respondents. The number of male respondents in this study was indicated $43.30 \%$ out of a total of 97 respondents recorded. The age that most participated in this study was $21-25$ years which amounted to $(60.82 \%)$. This age is a time when someone has just finished school in college in the not too distant future so that respondents are expected to have the right consideration in making decisions for a career. Respondents with age above 30 years and above are the smallest, namely as much as $7.20 \%$, while respondents aged between $26-30$ years amount to $31.98 \%$.

\subsection{Validity and Reliability}

To find out the question item is valid then it can be done by doing a correlation between the scores of the questions with the total score construct or variable. Significance is done by comparing the value of $r$ count with $r$ table. In this table $n=97$ and the magnitude of $\mathrm{df}$ can be calculated by $97-2=95$ with $\mathrm{df}=95$ and alpha $=0.05$. Whereas, the data reliability test is done using the Cronbach alpha method, which is an instrument said to be reliable if it has a reliability coefficient of 0.60 or more.

Table 2. Validity and Reliability for Study Variable

\begin{tabular}{|c|c|c|c|c|c|}
\hline No. & Variable & Item & Pearson Correlation & r-table & Cronbach Alpha \\
\hline \multirow{10}{*}{1} & \multirow{10}{*}{ Lifestyle (X1) } & 1 & .505 & 0,199 & \multirow{10}{*}{.725} \\
\hline & & 2 & .501 & 0,199 & \\
\hline & & 3 & .558 & 0,199 & \\
\hline & & 4 & .658 & 0,199 & \\
\hline & & 5 & .576 & 0,199 & \\
\hline & & 6 & .675 & 0,199 & \\
\hline & & 7 & .531 & 0,199 & \\
\hline & & 8 & .459 & 0,199 & \\
\hline & & 9 & .522 & 0,199 & \\
\hline & & 10 & .404 & 0,199 & \\
\hline \multirow{10}{*}{2} & \multirow{10}{*}{$\begin{array}{l}\text { Work Environment } \\
\text { (X2) }\end{array}$} & 1 & .636 & 0,199 & \multirow{10}{*}{.851} \\
\hline & & 2 & .458 & 0,199 & \\
\hline & & 3 & .630 & 0,199 & \\
\hline & & 4 & .705 & 0,199 & \\
\hline & & 5 & .752 & 0,199 & \\
\hline & & 6 & .608 & 0,199 & \\
\hline & & 7 & .807 & 0,199 & \\
\hline & & 8 & .671 & 0,199 & \\
\hline & & 9 & .600 & 0,199 & \\
\hline & & 10 & .724 & 0,199 & \\
\hline \multirow{10}{*}{3} & \multirow{10}{*}{ Carreer Path (X3) } & 1 & .744 & 0,199 & \multirow{10}{*}{.918} \\
\hline & & 2 & .779 & 0,199 & \\
\hline & & 3 & .797 & 0,199 & \\
\hline & & 4 & .711 & 0,199 & \\
\hline & & 5 & .828 & 0,199 & \\
\hline & & 6 & .798 & 0,199 & \\
\hline & & 7 & .767 & 0,199 & \\
\hline & & 8 & .771 & 0,199 & \\
\hline & & 9 & .707 & 0,199 & \\
\hline & & 10 & .701 & 0,199 & \\
\hline 4 & Money Oriented ( $\mathrm{Z})$ & 1 & .600 & 0,199 & .815 \\
\hline
\end{tabular}




\begin{tabular}{|c|c|c|c|c|c|}
\hline \multirow[t]{10}{*}{ No. } & \multirow[t]{10}{*}{ Variable } & Item & Pearson Correlation & r-table & \multirow[t]{10}{*}{ Cronbach Alpha } \\
\hline & & 2 & .565 & 0,199 & \\
\hline & & 3 & 684 & 0,199 & \\
\hline & & 4 & .642 & 0,199 & \\
\hline & & 5 & .657 & 0,199 & \\
\hline & & 6 & .551 & 0,199 & \\
\hline & & 7 & .599 & 0,199 & \\
\hline & & 8 & .624 & 0,199 & \\
\hline & & 9 & .595 & 0,199 & \\
\hline & & 10 & .613 & 0,199 & \\
\hline \multirow{10}{*}{5} & \multirow{10}{*}{$\begin{array}{c}\text { The Selection of } \\
\text { Accounting } \\
\text { Profession }(\mathrm{Y})\end{array}$} & 1 & .668 & 0,199 & \multirow{10}{*}{.893} \\
\hline & & 2 & .675 & 0,199 & \\
\hline & & 3 & .711 & 0,199 & \\
\hline & & 4 & .752 & 0,199 & \\
\hline & & 5 & .765 & 0,199 & \\
\hline & & 6 & .858 & 0,199 & \\
\hline & & 7 & 681 & 0,199 & \\
\hline & & 8 & .751 & 0,199 & \\
\hline & & 9 & .694 & 0,199 & \\
\hline & & 10 & .620 & 0,199 & \\
\hline
\end{tabular}

\subsection{Diagnostic Test Result}

Normality Test Result

A regression equation is said to pass normality if the significance value of the Kolmogorov-Smirnov test is greater than 0.05 . The results of the normality test performed indicate that the data is normally distributed. This is indicated by a significance value of $>0.05$. From table 5.7 it can be seen the significance of the Kolmogorov-Smirnov value which is above the $5 \%$ confidence level of 0.200 , indicating that the data is normally distributed.

Table 3. Test for Normality for Study Variable

\begin{tabular}{cccc}
\hline One-Sample Kolmogorov-Smirnov Test & & & \\
\hline & Statistic & df & sig. \\
\hline The Selection of Accounting Profession & 0.56 & 95 & $.200^{*}$ \\
\hline
\end{tabular}

\section{Test for Multicolinearity}

Multicollinearity can also be seen from (1) tolerance value and the opposite (2) variance inflation factor (VIF). If a low tolerance value is equal to a high VIF value (because of VIF $=1$ /Tolerance). The cut-off value commonly used to indicate the presence of multicollinearity is the Tolerance Value $\leq 0.10$ or equal to the VIF value $\geq 10$. In Table VIF value for all variables has a value smaller than 10 and tolerance value is greater than 0.10 , it can be concluded that there are no symptoms of multicollinearity between independent variables.

Table 4. Test of Multicolinearity Result

\begin{tabular}{ccc}
\hline Variable & Tolerance & VIF \\
\hline Lifestyle & .845 & 1.184 \\
Work Environment & .768 & 1.301 \\
Career Path & .737 & 1.358 \\
\hline
\end{tabular}

\section{Test of Heterocedasticity}

Heteroscedasticity test is to test whether the regression model occurs in variance from residual inequalities, one observation to another observation. In this study use glejzer test for heterocedasticity test if the variant of the residual one observation to another observation remains, then it is called homoskedasticity and if it is different it is called heteroscedasticity. The Glejzer test results in Table 5 
below, it can be seen that the probability for the independent variables of lifestyle, work environment and career path is the significance level (sig) above the $5 \%$ confidence level. So, it can be concluded that the regression model does not contain any Heteroscedasticity.

Table 5. Test of Heteroscedasticity for study variable

\begin{tabular}{ccc}
\hline Variable & Test & Sig. \\
\hline Lifestyle & Glejzer & .787 \\
\cline { 2 - 2 } Work Environment & Glejzer & .828 \\
Carreer Path & Glejzer & .422 \\
\hline
\end{tabular}

\subsection{Discussions}

Multivariate linear regression model linking lifestyle, work environment and career path shows that there are relationships on selection of accounting profession. $R=0.704$ and $R^{2}=0.49549 .5 \%$ which mean that the selection of the accounting profession is influenced by lifestyle, work environment and career path. The remaining $50.5 \%$ is influenced by other variables that have not been studied in this study.

Table 6. Model Summary for the selection of accounting profession

\begin{tabular}{ccccc}
\hline Model & R & R Square & Adjusted R Square & Std. Error of the Estimate \\
\hline 1 & $.704^{\text {a }}$ & 0,495 & 0,479 & 4,569 \\
\hline
\end{tabular}

Based on table 7 shows that lifestyle variables have a significance level of 0.048 which is smaller than 0.05. So this shows that lifestyle influences significantly on the selection of the accounting profession. Thus, the first hypothesis which states lifestyle has a significant effect on the selection of the accounting profession is accepted. These results indicate that the higher the lifestyle a person has, the more one's intention in choosing the accounting profession for a career increases.

The work environment variable has a significance level of 0,000 which is smaller than 0.05 . So this shows that the work environment has a significant effect on the selection of the accounting profession. Thus, the second hypothesis which states the work environment has a significant effect on the selection of the accounting profession is accepted. These results indicate that the higher the standard work environment a person has, the higher one's intention in choosing the accounting profession for a career.

The career path variable has a significance level of 0,000 which is smaller than 0.05 . So this shows that the career path significantly influences the selection of the accounting profession. Thus, the third hypothesis which states the career path significantly influences the selection of the accepted accounting profession. These results indicate that the higher the career level standards a person has, the lower one's intention in choosing the accounting profession for a career.

Table 7. Multivariate Analysis for the selection of accounting profession

\begin{tabular}{ccl}
\hline Variable & B & Sig. \\
\hline Lifestyle & .219 & .048 \\
Work Environment & .425 & .000 \\
Career Path & .323 & .000 \\
\hline
\end{tabular}

In this study we use Moderating regression analysis for hypothesis testing on money oriented. The result shows that the $\mathrm{R} 2$ value is 0.610 , which means $61.0 \%$ of the interaction variable between lifestyle, work environment and career level is money oriented is one of the moderating variables. The remaining $39 \%$ is influenced by other variables not examined in this study.

Table 8. Model Summary for moderated variable

\begin{tabular}{ccccc}
\hline Model & $\mathbf{R}$ & R Square & Adjusted R Square & Std. Error of the Estimate \\
\hline 1 & $.781^{\mathrm{a}}$ & 0,610 & 0,598 & 4.014 \\
\hline
\end{tabular}

Table 9 below show that Moderation variable X1Z with a significance level of 0.045 which is smaller than 0.05 . This means that money oriented variables are moderating variables that strengthen or weaken 
the relationship of lifestyle variables to the selection of the accounting profession. Moderation variable X2Z with a significance level of 0.031 that is smaller than 0.05 . This means that money oriented variables are moderating variables that strengthen or weaken the relationship of work environment variables to the selection of the accounting profession. Moderation variable X3Z with a significance level of 0.041 which is smaller than 0.05 . This means that money oriented variables are moderating variables that strengthen or weaken the relationship of career level variables to the selection of the accounting profession.

Table 9. Moderating Regression Analysis for selection of accounting profession

\begin{tabular}{ccc}
\hline Variable & B & Sig. \\
\hline $\mathrm{X} 1 \mathrm{Z}$ & .005 & .045 \\
$\mathrm{X} 2 \mathrm{Z}$ & .005 & .031 \\
$\mathrm{X} 3 \mathrm{Z}$ & .004 & .041 \\
\hline
\end{tabular}

The Impact of Lifestyle on the Selection of Accounting Profession

Based on the results of the analysis show that lifestyle influences significantly towards the selection of the accounting profession. This means that the higher the lifestyle that is owned by someone then the intention to choose the accounting profession will also be increasingly level, thus the first hypothesis is accepted. the higher the level of lifestyle oriented with interest related to accounting such as analysis, evaluation and something systematically arranged in an accounting scholar personally, the higher the desire of accounting scholars to choose the accounting profession as a goal for a career. This statement is also supported by the results of research which state that interest factors are the highest indicators among indicators of activity and opinion.

This study is support Holland theory (1973) through vocational personalities and work environment theory that explained the relation of lifestyle in choosing a job. In his theory said that someone is interested in a particular career because of his personality and surrounding environment. Career choice is also an expression of someone into the world of work by identifying certain choices. In this theory describes the category of conventional named individuals who discuss hobbies, activities and environments that have relevance to people who work in the financial sector, such as people who are happy with a systematically structured language, evaluating, analyzing and others.

As for previous studies that strengthen this relationship. In the research conducted by Djatej et al. (2015) explained the factors of students majoring in accounting. The author provides one factor that concerns a person's interest in choosing an accounting department, namely personal interest. In this study states that personal interest gives a positive influence on someone in choosing an accounting department.

\section{The Impact of Work Environment on The Selection of Accounting Profession}

Based on the results of the analysis show that the work environment has a significant effect towards the positive choice of the accounting profession. This means that the higher the suitability of the perceptions of the accounting work environment with the work environment offered by the accounting profession, the higher the intention to choose the accounting profession. Supported by research results stating that non-physical work environment factors such as assignments, work pressures, and relationships between individuals in the accounting firm are the most influential for the mindset of undergraduate accounting as a consideration compared to physical work environment factors such as room conditions, lighting and air conditioner.

This study supports the theory of self-concept by Super (1974) which states that physical and mental growth, the general environment, and experience in general is a self-concept that is a driver that forms a career pattern that will be followed by individuals throughout their lives. The higher the level of similarity of perceptions of the work environment expected by accounting scholars with a standard work environment in the accounting profession both physically and non-physically, the intention to choose the accounting profession for a career will increase, because the scope of work as an accountant supports a person to continue developing, work that requires high accuracy and some work conditions that are expected to exist within the scope of the accounting profession. 
This research also supports the research conducted by Kania (2013) which states that the accounting profession is more routine and many jobs can be completed behind the desk. While the work as a public accountant is more attractive, more requires time, the level of competition and the amount of pressure.

The Impact of Career Path on The Selection of Accounting Profession

Based on the results of the analysis show that the career path significantly influences towards the selection of the accounting profession. This means that the higher the career path offered by the accounting profession to accounting scholars, the intention to choose the accounting profession will be higher, thus the third hypothesis is accepted. The better the accounting profession career program offered by a company or accounting office, the intention of undergraduate accounting to choose the accounting profession for a career will increase. There are expectations from undergraduate accounting that a good career path can motivate increasing expertise in accounting. The dimensions of exposure in the career path are the most influential dimensions in career path variables. This dimension emphasizes how someone is motivated through the show off process or introducing expertise to the company, such as giving responsibility for completing important tasks outside of the task that is supposed to, so that it encourages the development of accounting skills of accounting scholars.

This study also supports Vroom's theory of hope (1964) stating that the motivation of an individual leads to an action that depends on the power of hope. This theory argues that someone will be motivated to do something to achieve the goal if they believe that their behavior leads to achieving that goal. The accounting profession has a gradual and systematic career path projection that motivates accounting scholars to choose the accounting profession as a goal for a career.

This research also supports the research conducted by Jean and Mathieu (2015) in his research on how a person can survive as an entrepreneur with one of the factors based on the satisfaction of his career. This study states that career development satisfaction has a relationship with how one can survive to become an entrepreneur.

The Effect of Money Oriented in Moderating the Relationship of Lifestyle to the Selection of Accounting Professions

Based on the results of the analysis show that the interaction between money oriented and lifestyle influences the selection of the accounting profession. The acquisition of the amount of finance offered as an accountant in the company is quite promising, so that it can encourage an accounting scholar with a lifestyle that is attached to (conventional) accountants more motivated to take the job because of the number of achievement offered.

Achievement factor which is something that is closely related to the physical award given by the accountant's office to the accounting scholar. Through a statement on the bonus given to the achievers who answer agree, accounting scholars perceive that the achievement dimension is closer to agreeing. So that through the results of the research test it can be concluded that the financial gain given to an accountant is a factor that encourages someone who has an interest in accounting to further strengthen the determination to choose the accounting profession as a goal for a career.

The results of this study also support the theory of Ginzberg et al. (1951) regarding the existence of causes of someone experiencing irregularities in their career decision making. Ginzberg stated that variables such as emotional instability, personal problems and financial wealth are causes of irregularities that are not in accordance with one's interests. In this case one of the supporting variables of occupational choice theory Ginzberg et al. (1951) that financial wealth is perceived as behavior towards money in this study, so this study supports occupational choice theory. The research stated by Kraus (2017) which states that money can affect a person's lifestyle and environment. Rich people tend to be more narcissistic and think they are more capable and capable than ordinary people, whereas those who are not rich on the contrary have a lower level of control of the surrounding environment and tend to be more usually empathetic, loving and kind.

The Effect of Money Oriented in Moderating the Relationship of Work Environment to the Selection of Accounting Professions

Based on the results of the analysis show that there is an interaction between money oriented and the work environment influences the selection of the accounting profession. Accounting scholars consider 
money to be an important factor in work, money oriented is represented as salary, bonus and financial rewards as dimensions of achievement. Financial gain obtained when working as an accountant motivates a person to become an accountant, but that is only a supporting factor because in every job they must get a salary, bonus and other financial rewards. The accounting profession is a profession that has a work environment full of challenges and pressures such as assignments carried out for months outside the area, conducting stock taking for hours to days and auditing financial statements, so that saturation is often created when undergoing this work. So with the incentives and bonuses given, it will motivate accountants to continue to undergo the accounting profession and can also be a reference for accounting scholars to choose the accounting profession as a goal for a career.

The results of this study also accepted the theory from Ginzberg et al. (1951) regarding the existence of two reasons for someone experiencing irregularities in their career decision making. Ginzberg stated that variables such as emotional instability, personal problems and financial wealth are causes of irregularities that are not in accordance with one's interests. This result also supports research written by Kraus (2017) which states that money can influence a person's lifestyle and environment.

The Effect of Money Oriented in Moderating the Relationship of Career Path to the Selection of Accounting Professions

Based on the results of the analysis show that the interaction between money oriented as a career path influences the selection of the accounting profession. Accounting scholars consider money to be an important factor in work, money oriented is represented as salary, bonus and financial rewards as dimensions of achievement. Financial gain obtained when working as an accountant motivates a person to become an accountant, but that is only a supporting factor because in every job they must get a salary, bonus and other financial rewards. This is also supported by the results of this study which states that the dimensions of achievement or statement as well as statements about bonuses given to people who are achievers are one pattern of a career path. So that it can be stated that financial awards offered by companies can strengthen the company's career path standards so as to strengthen the influence of undergraduate accounting in choosing the accounting profession as a goal for a career.

Expectation theory by Vroom (1964) argues that someone will be motivated to do something to achieve the goal if they believe that their behavior leads to achieving that goal. . In this study proves that money factors become the main and supporting factors in influencing a choice or decision making. Most companies reward employees in financial terms. So employees choose a job because the career that will be passed is filled with many financial awards and high salaries from the company.

This study also supports Sartono's research (2018). In this study regarding Turn-Over Intention or comparison between the entry and cessation of employees in a company. In the study it was found that one of the variables that significantly affected was the variable regarding compensation while compensation itself is something in the form of money or goods received by employees of the company.

\section{Conclusions}

1. Lifestyle influences the selection of the accounting profession. This means that lifestyle improvements have a positive impact on the intentions of a graduate of Hasanuddin University in choosing the accounting profession as a goal for a career.

2. The work environment influences the selection of the accounting profession. This means that the increase in the perception of the work environment has a positive impact on the intention of a graduate of Hasanuddin University accounting in choosing the accounting profession as a goal for a career.

3. Career paths influence the selection of the accounting profession. This means that the increase in the perception of career paths has a positive impact on the intention of a graduate of the University of Hasanuddin accounting in choosing the accounting profession as a goal for a career.

4. Money Oriented can moderate the influence of lifestyle, work environment and career paths on the selection of the accounting profession. 


\section{Implications and Limitations of Research}

Implication of this research is the findings in this study can contribute theorists to scientific developers in the field of accounting profession career guidance, where empirical evidence related to the influence of several factors that are considered to influence one's intention in choosing the accounting profession as a career goal can be a reference in further research. The results of this study can contribute to academics and practitioners in terms of fostering and guiding prospective graduates in the field of accounting in increasing interest and desire for a career and work in the field of accounting.

Limitation of this research is the independent variables used in this study are still limited. The coefficient of determination is $49.5 \%$ independent variable which explains the variable of the accounting profession selection. This means that outside the variables under study there are still other variables that influence the selection of the accounting profession by $50.5 \%$. The sample in this study is limited to graduates of accounting at Hasanuddin University graduates from 2013-2017 so that the results and conclusions of this study cannot be generalized for all accounting graduates in Indonesia.

\section{Suggestion}

It is hoped that the academics can pay attention to the lifestyle factors of the students. How academics can facilitate prospective accounting graduates to develop perceptions of their interest in accounting and provide positive knowledge and opinions on how to pursue a career in the accounting world and the scope of the accounting profession to accounting students who intend to pursue careers as accountants. It is hoped that academics can provide more knowledge and training regarding the situation and conditions of the accounting profession and provide training as practitioners of the accounting profession who will be followed later after graduating from college, so that prospective accountants can compete well in the environment job and ready to face the reality of the world of work.

\section{References}

1. Abazeed, R. A. M. (2019). The Impact of Talent Management on Organizational Commitment of the Employees of Telecommunication Companies in Jordan: The Mediating Role of Employee Work Engagement. IJARAFMS. Vol. 8, No.4.

2. Abidin, Z. (2017). Analysis Of Factors Affecting Students Choose The Economic Accounting Profession As A Publik Accountants. Journal of Accounting. Vol. 3, No.3.

3. Ginzberg, E., Ginsburg, S.W., Exelrrad, S., dan Herma. (1951). Occupational Choice: An Approach to General Theory. Columbia University Press, New York.

4. Holland, J.L. (1973). Making Vocational Choices. Third Edition. Psychological Assessment Resources, Inc.

5. Jean, E. dan Mathieu C. (2015). Developing Attitudes Toward an Entrepreneurial Career Through Mentoring: The Mediating Role of Entrepreneurial Self-Efficacy. Journal of Carrier Development. Vol. 42(4).

6. Kotler, P. dan Gary A. (2014). Principle of Marketing. $15^{\text {th }}$ edition. New Jersey: Pearson Prentice Hall.

7. Kraus, M. (2017). Penelitian Ilmiah: Punya Banyak Uang Mengubah Sifat Seseorang. Vice Media Online. Accessed May 8, 2018) https://www.vice.com/id_id/article/7xzqz9/penelitian-ilmiah-punyabanyak-uang-mengubah-sifat-seseorang,

8. Lazer, W. (1963). Symbolism and Life Style, in Toward Scientific Marketing (Ed.) Stephen A. Greyser, American Marketing Association, II:140-149.

9. Mahyarni (2013). Theory of Reasoned Action dan Theory of Planned Behaviour (A Historical Study of Behavior). Jurnal El-Riyasah. Vol. 4, No. 1.

10. Nitisemito, A.S. (2014). Manajemen Personalia. Jakarta: Ghalia Indonesia.

11. Pigo, N, Sudrajat and Neny D. (2013). Mengapa Semakin Banyak Jumlah Alumni Akuntansi Tidak Sebanding Dengan Pertumbuhan Kantor Akuntan Publik (Persepsi Mahasiswa Akuntansi Terhadap Profesi Akuntan Publik Setelah UU No. 5 Tahun 2011 Tentang Akuntan Publik). Jurnal Akuntansi dan Keuangan Vol. 3 No.1. Faculty of Economics and Business. University of Lampung. 
12. Pusat Pembinaan Profesi Keuangan. 2017. Penilaian Resiko Sektoral Akuntan dan Akuntan Publik Terhadap Tindak Pidana Pencucian Uang di Indonesia Tahun 2017. (Online), (http://pppk.kemenkeu.go.id/ Dokumen/GetPdfFile?fileName=SRA\%20-\%20Bilingual.pdf)

13. Rivai, V, Mansyur R, Mutis and Arafah. (2018). Manajemen Sumber Daya Manusia Untuk Perusahaan Dari Teori Ke Praktik. Edisi ke 3. Jakarta: PT Raja Grafindo Persada.

14. Sartono, M. (2018). Effects of Compensation, Work Motivation and Organizational Commitment to Turnover Intention. Journal of Management. Vol. 4, No. 4. ISSN: 2502-7689.

15. Sedarmayanti (2013). Sumber Daya Manusia dan Produktivitas Kerja. Bandung: Mandar Maju.

16. Sunyoto, D. (2014). Konsep Dasar Riset Pemasaran \& Perilaku Konsumen. Yogyakarta: CAPS.

17. Sugiyono (2013). Metode Penelitian Kuantitatif, kualitatif \& RND. Bandung: Alfabeta.

18. Super, D. E. (1957). The Psychology of Careers: An Introduction to Vocational Development. First Edition. New York: Harper \& Row.

19. Tang, T. (1992). The Meaning of Money Revisited. Journal of Organizational Behavior. 13: 197202.

20. Tang, T. (2002). Is the love of money the root of all evil? Or different strokes for different folks: lessons in 12 countries. Paper presented to the International Conference on Business Ethics in the Knowledge Economy. Hong Kong, China.

21. Tang, T., Tillery, K., Lazarevski, B., dan Luna-Arocas, R. (2004). The love of money and Work Related attitudes: money profiles in Macedonia. Journal of Managerial Psychology. 19(5): 8-542.

22. Tang, T., Y. Chen, dan Sutarso T. (2008). Bad apples in bad (business) barrels: The love of money, machiavellianism, risk tolerance, and unethical behavior. Management Decision. 46 (2): 63-243.

23. Tang, T.L.P. and Chiu, R.K. (2003). Income, Money Ethics, Pay Satisfaction, Commitment, And Unethical Behavior: Is The Love Of Money The Root Of Evil For Hong Kong Employees. Journal of Business Ethics, 46: 13-30.

24. Tang, T.L.P. David Shin-Hsiung Tang, Roberto Luna-Arocas (2005). Money Profiles: The Love of Money, Attitudes, and Needs. Personal Review. 34(5): 603-624.

25. Tang, T.L.P., Kim J.K. and Tang, D.S.H. (2000). Does attitude towards money moderate the relationship between intrinsic job satisfaction and voluntary turnover, Human Relations, 53(2): 213-245.

26. Vroom, V. H. (1964). Work and Motivation. New York: John Wiley \& Son, Inc.

27. Yeltsinta. R. and Fuad. (2013). Love of Money, Pertimbangan Etis, Machiavellian, Questionable Action: Implikasi Pengambilan Keputusan Etis Terhadap Mahasiswa Akuntansi dengan Variabel Moderasi Gender. Diponegoro Journal Accounting. Vol. 2, No. 3, 2013. ISSN: 2337-3806. 